\title{
Platon ve Heidegger'de Aletheia ve Sanat Yapıtı İlişkisi
}

\author{
Derviş Atahan
}

\section{Zehragül Aşkın}

Özet: Gizlenmemişlik üzerine ontolojik ve epistemolojik bir farkındalığa karşıllık gelen aletheia, Platon ve Heidegger in düşünce dizgesinde temel bir konuma sahiptir. Her iki düşünür de kavramın yalnızca kökenine ve olanağına ilişkin bir inceleme yapmakla kalmamış aynı zamanda kavramın sanat yapıtı ile olan ilişkisinde açığa çıkan varoluş biçimlerinin kökensel değerine ilişkin bir sorgulama gerçekleştirmişlerdir. Biliş ve varoluş arasındaki ilinti, kendisinden hakikatin bilinebileceği varoluş biçimleri zemininde değerlendirildiğinde Platon için insanın akıl ve beden kapasitesinin kendi ontik ve epistemolojik varlığıyla doğrudan ilişkilendirildiği hiyerarşik bir onto-pistemolojik kavrayışa; Heidegger için ise ontik olanın, yalnızca ontik olan olması yeterliliğinde bilmeye kapı araladığı ve bu sayede de sanat yapıtı varoluşu dahil her bir varoluşun bilme edimiyle ilişkilendirilebildiği bir kavrayışa çıkmaktadır.

Anahtar Kelimeler: Aletheia, Sanat Yapıtı, Platon, Heidegger, Bilgi

\section{Aletheia and Artwork Relationship in Plato and Heidegger}

\begin{abstract}
The concept of Aletheia which corresponds to an epistemological and ontological awareness over about the disclosedness, occupies fundemental places in the thought-systems of both Heidegger and Plato. Either of the philosophers have not only made an examination on the origin and the possibility of this concept; but they have also made an inquiry on the original value of its existence-forms, which are revealed in the relationship of the concept with the work of art. The relation between cognition and existence is a hierarchical onto-epistemological conception of Plato, where the human mind and body capacity is directly related to its ontic and epistemological existence when evaluated in the context of the forms of existence that it can know the truth from; for Heidegger, the ontic opens a door to knowing that because it merely an ontic is, and in this way comes an understanding that every existence, including the existence of the artwork, can be associated with the act of knowing.
\end{abstract}

Keywords: Aletheia, The Work of Art, Plato, Heidegger, Knowledge

Derviş, Atahan. Aşkın, Zehragül. (2017). Platon ve Heidegger'de Aletheia ve Sanat Yapıtı İlişkisi. Kilikya Felsefe Dergisi (2). ss. 51-68. 


\section{Giriş}

Aletheia kavramı, hem Platon'un hem de Heidegger'in felsefi düşüncelerinin merkezini oluşturur. Makale Platon'da epistemolojik ve ontolojik, Heidegger'de ise ontolojik içerime sahip olan kavramı her iki düşünürün sanata yaklaşımları perspektifinden ele almakta ve aletheiasanat yapıtı ilişkisinin her iki düşünürün felsefe yapma etkinliğinde hangi kavram çatıları altında temellendirildiğini konu edinmektedir.

Aletheia kavramı Heidegger'de ontik olanın ontikliğinin açımı olarak gizli bulunanın açı̆̆a çıkması bağlamında hakikatin gerçekleşmesi anlamında kullanılsa da kavramın ele alınışında öncelik Platon'a aittir. Çünkü aletheia kavramı Platon'da bilginin kaynağı, değeri ve sınır sorularına verilen yanitlarda temel bir yerdedir. Aletheia kavramı Platon'da bir hakikat tanımlaması olmanın yanında ontik ve epistemolojik olan üzerine oluş ve bozuluşa aşkın bir objektivite tasarımıdır.

Aletheia (Yun. ád $\Lambda \eta ি \theta \eta$ - unutma) kelimesinin Yunanca'daki 'a-' olumsuzlama ekiyle olumsuzlanması yoluyla oluşturulmuş "unutulmuş, saklanmış olanın açı̆̆a çıkartılması" anlamına gelir. ${ }^{1}$ Kelimenin türediği lethe kavramı aynı zamanda Antik Grek'lerde ruhun ölüm sonrası yaptığı yolculuktan metaforik izler taşır. Hades' in yeraltı ölüler diyarında ruh, letheırmağından tatmasıyla ölümlüler dünyasında yaşadığı her anıyı unutmakta ve bildiği herşeyi zihninden silmektedir. Irmaktan içmek, yaşam boyunca edinilmiş herşeyin kaybedilmesi anlamina gelir. ${ }^{2}$

Felsefe literatüründe aletheia kavramı 'hakikat (Ing: truth)' olarak anlamlandırılmaktadır. Bu anlamlandırmanın Antik Yunan'daki arka planında, antik felsefede hakikatin sürekli ilerleyen bir tarih çizgisinde sonu keşfedilmemiş bir süreci okumaktan ziyade, evrene hakim yaratıcı yasa (logos) ve yasa koyucu tarafından halihazırda verilmiş olanın bulunması ve bilinmesi olduğu anlayışı bulunmaktadır. Bu açıdan aletheia, var olan hakikatin olduğu şekliyle her bir yeni yaşamda yeniden

3 Aletheia: Meydana -çıkma, açığa çıkma, gizinden çıkma, görünüverme (Peters, 2004:32).

2 Platon Devlet X. Kitapta (614b-621a) Lethe irmağı ve 'zihin boşalımı, unutkanlık (unmindfulness)' ilişkisinden bahseder. Hikâye Pamphylia'lı Armenius'un oğlu Er'in ruhunun ölüm sonrası bedenden ayrılması, yeraltındaki yolculuğu ve tekrar yeryüzüne yükselişini konu eder.

Lethe nehri (River of Forgetfulness), Grek mitolojisinde beş cehennem nehrinden (Styx, Aecheron, Kokytos, Pyriphlegethon, Lethe) biridir ve ölüm sonrası bilincin silinmesini temsil eder (Hard, 2004: 109-110). 
keşfedilmesi anlamına da gelir.

Kelimenin anlamı lethe'nin 'unutmak ve unutkanlık' anlamina gelen kökenine dayanır. Bu aslına uygun çeviride aletheia, hakikatin evriminin kültürler arası bağlamına dair kullanışlı bir çerçeve sunar. Değişik kültürler ve değişik toplumlar geçmişteki değişik hikayelerini hatırayabilir ve ya kayıt edebilirler. Fakat tüm bu hatırlama ve kayıtları onların 'geçmişleridir'. Aletheia geçmişin kayıtlarına eşit ölçüde bakmamıza ve incelememize izin verir (Monchamp, 2008).

Felsefe tarihinde Platon'un özgünlügü Yunan felsefe tarihinde felsefeyi ilk kez tarihe, topluma ve devlete uygulanabilecek şekilde sistematize etmesinin yanında aletheia ve sanat yapıtı ilişkisini temellendirmiş olmasıdır. Platon'un aletheia ve sanat ilişkisini konu edinmesinin arka planını onun çağının felsefe yapma etkinliğinin çerçevesini belirleyen bilgi ve varlık anlayışlarıyla hesaplaşması oluşturur. Bu hesaplaşmanın sonunda Platon özgün epistemoloji ve ontolojisini oluşturmuştur. Sanat felsefesi bağlaminda Platon felsefesinin özgünlüğü ise, Platon'un mimetik bir faaliyet olarak gördüğü sanatsal ve zanaatsal eylemleri, kendi bilgi ve varlık kuramı üzerinden şekillenen bir eleştiriye tabi tutması ve bu faaliyetleri aletheia ile ilgisinde temellendirmesidir. Ona göre sanatın yansıttığı görünüşler evreni ve ilişikleri, hakikatin yalnızca bir yönüdür. Ancak hakikat birbirini tamamlayan ideasal ve görünüşsel olmak üzere düalist bir yapıdadır. Platon için sanatın salt taklitçi yönü, hem epistemolojik bağlamda bir yetersizlik ve cahillik; hem de gerçeklik olarak kabul edildiği taktirde toplumsal bir yozlaşmadır. Zira sanat, görünüşler evreninde yaşayan insan açısından bir hakikat kovalamacası değil, yalnızca hiyerarşik epistemolojinin en alt tabakasının aldatıcı etkinliğidir. Platon için hakikat, evrenin hakikati olmakla birlikte insanın kendi hakikatidir; hakikati bilmek insanın kendini bilmesidir. Zira evrene hakim olan evrensel idea yasasını kavramak insanın ontik ve epistemolojik olarak evrenin gerçekliğini, insan varlığının ve bilgisinin bu idea yasasına tabi olması dolayısıyla da kendi varlık gerçekliğini kavramasıdır. Bu sebeple mimetik uğraş bir yabancılaşma pratiğidir.

Aletheia kavramının hakikatin bilinmesi anlamındaki tanımını miras alan Heidegger, Platon'un sanatsal eylem ve hakikatin gerçekleşmesi arasındaki olumsuz gerilimi yeniden yorumlayarak sanatsal eylemi yine bir var oluş olarak hakikatin gerçekleşmesi anlamında olumsuz 
olmayan bir bağlamda temellendirmiştir. Heidegger, varlığa gelmeyi ya da var oluşu, Platon'da ideanın merkez alındığı hiyerarşiden kopararak "var olmak olarak varoluş " şeklinde yorumlamış, böylelikle sanatsal eylemdeki varlık açılımını diğer varlık açılımlarıyla denk görmüştür. Böylelikle Heidegger sanatsal eylemi, hakikatin gizini açığa çıkarmanın yollarından biri olarak okumaktadır. Sanatsal eylem, gerçekleştiği zamanmekanda bilişsel bir tanım alanı yaratmaktadır. Bu yüzden bu eylemsellik ontik olanın tanımlanması ve ya yorumlanması olarak bir varlığa gelme ve bir açmadır.

\section{I}

İnsan kelimesinin Antik Yunan'daki karşılığı olan anthropos kelimesi içinde insanı diğer varlıklardan ayıran basit bir noktaya dair ipucu taşır. Kratylos diyaloğu'nda Sokrates'ten duyduğumuza göre; kelimenin içinde barınan opope (görmek, - görür görmez, görme anı) içerimi, insanın gördüğü şeye görmesi ardından düşünme edimini uygulamasıyla ilgilidir. Kişi gördügüüü düşünür (Platon, 2010: 398e-399d). İnsanın anathron ho opope, yani gördügünü inceleyen canlı olması insanda ruh ve beden düalizmiyle bağlantılıdır. Antik Grekler ruhumuzu ve bedenimizi birbirinden ayrı iki varlık alanı olarak tasarlamışlardı. Ruh (psykhe), bedenin yaşama nedenidiydi, bedene yaşamsal özelliklerini kazandıran, zamanı gelince bedeni terk ederek yaşamsal özelliklerini ondan alan ruhtu. Ruh, yalnızca bedenin değil tüm yaşamın yaşamsal ilkesiydi (Platon, 2010: 399e-400b). Görülür görülmez üzerine düşünmek ediminde ruh ve bedenden hangisinin gördüğü ve hangisinin düşündüğü; görülenden ve düşünülenden hangisinin bilgi olduğu ve hangisinin algı olduğu ve ya ruh ve bedenden hangisinin bilen ve hangisinin algılayan olduğu ilişkisi maddesel olanla tinsel olan arasındaki savaşımın ifadesidir. Bu savaşım Platon'da kendini maddi reel dünya ve tinsel idealar dünyası ikiliğiyle fakat aynı zamanda insanın maddesel tarafı ve tinsel tarafı arasındaki çatışkı şeklinde kendini gösterecektir.

Aletheia kavramıla yakından ilişkili en temel ve en önemli kavram anamnesis (Yun: ávóuvๆoıs: hatırlama) kavramıdır. Anamnesis hakikatin adım adım anımsanmasıdır. Anamnesis, ruhun lethe ile kaybettiği bilgiyi hatırlaması olarak epistemolojik bir içerime sahip görünür. Yine de unutmayı daha sonra Heidegger'in opus magnumu olan Varlı ve Zaman'da sıklıkla dile getirdiği varlığın hakikatinin unutulması olgusu ile olan ilişkisi bağlamında ele aldığımızda anamnesis'in ontolojik içerimi 
hakkında bir ipucu elde edebiliriz. Anamnesis, unutulmuş olanın fark edilmesi anlamında bilmemezlik (ruhta unutulmuş olarak saklı bulunanın bilinmemezliği) üzerindeki bir hatırlayıştır. Kişi, anamnesis yoluyla-artıkbildiği şeyi daha önce bilmediğinin farkındalığıyla hâlâ bilmediği şeylerin de var olabileceğini çıkarsamaktadır. Kişi "bilmediğinin bilgisine "3" sahip olmaktadır. Diyebiliriz ki anamnesis Sokrates'in ünlü desturu 'kendini bil!'in ön adımıdır.

Anamnesis, sanılardan doğrulanmış doğru bilgiye doğru ilerleyen bilme sürecinin temel hafıza aktivitesidir. Bu aktivite, fenomen dünyada bilinebilir olanı açığa çıkarmak için gerçekleştirilen bir yeniden toparlama ve hatırlama pratiğidir. Aletheia ise, ölümle birlikte insanın fenomen dünyada edindiği bilginin unutulmasının ya da başka deyişle insanın epistemolojik ve ontolojik kapasite ve varlığının an'daki durumunun olumsuzlanmasının ikincil bir olumsuzlanması anlamına gelmektedir. İnsan bilinci ölümle birlikte bilinç kapasitesini yitirir ve bilincin yok oluşu aynı zamanda hakikat üzerine farkındalığın yok oluşudur. Antik Yunan'daki bu ölüm sonrası bilinci yitirme problemi, ruhun ölümsüzlüğü kabulü ve yeniden hatırlama yani anamnesis edimiyle birlikte giderilebilir bir durum olarak görünür. Lethe, insan zihnindeki hakikat algısının, unutma yoluyla yok edilmesidir. "Aletheia, unutmanın antitezidir. Aletheia edinilir olanlar arasından unutulmuş olanı, donuklaşmış olanı,

3 Sokrates, kendi bilgeliği üzerine açıklamada bulunurken var olabilecek tek bilginliğin; başka insanların bir şey bilmediklerini bilmemelerine karşın insanın en azından hiçbir şey bilmediğinin bilgisine sahip olmak sayılabileceğini söylüyor (Platon, 2010:20d- 21e). $\mathrm{Bu}$ anlamda Sokrates'in tarif ettiği bilgelik bilgisizliğin bilincinde olmak anlamında bir farkındalıktır. Bu bilgelik toplumda algılananla çelişik biçimde ne bir üstünlük nişanı ne de yerleşik toplumsal kuralları pekiştirene verilen ilerici bir sıfattır. Bunun yerine bu tarz bir bilgelik, toplumun yoz kural ve tanımlarının yıkıma uğratılarak elde edilecek bir farkında olma durumudur. Öyle ki toplumda bilgi olarak bilinen her şey kendisinin yanlış olmasının yanında başka bir yanlışa da kapı aralamaktadır. Bu zincirleme reaksiyon toplumun politik, sosyolojik ve ekonomik yapısında hakikat ile uyuşmayan yoz kurum ve makamları beslemektedir. Bu bağlamda 'bilmediğinin bilgisine' sahip olmak, toplumda yerleşik her şeyin kritik edilmesiyle elde edilen bilgidir. Platon için bilgeleşmeye başlamak aynı zamanda toplum içinde yalnızlaşmaya başlamak demektir. Başka deyişle gerçekliği bilmeye başlayan kişi Sokrates'in ağzından duyduğumuz üzere antik toplumun içinde yaşadığı karanlığı görmekte ve bu karanlığa ne pahasına olursa olsun geri dönmek istememektedir. Mağara Alegorisinde anlatılacağı üzere zihni gerçekliği algılayan ve gözleri gerçekliği gören birisi için eski toplumda barınmak giderek zorlaşmaktadır. Bir kere lethe'yi tersine işletmeye başlayan ruh; yani unutturulmuş hakikati tekrar hatırlayan ve dolayısıyla bilmeye başlayan ruh artık daha yukarıyı arzulamaktadır. "Bir kez buraya (mağaranın dışına çıkmakla başlayan bilgelik sürecine) çıkmış insanların, artık insanların meseleleriyle uğraşmak istemeyişlerine de hayret etme! Onların ruhları artık oralarda kalmak üzere, daha yukarıya tırmanmak için zorlar onları" (Platon, 2009: VII: 517c). 
gizlenmiş olanı geri getirir" (Moles, 2015:2).

Aletheia kavramının ölüm Tanrısı Hades'le ve ölümle ilişkisi düşünüldüğünde aletheia'nın, insan varlığının ölüler diyarında uğradığı bozuma karşı bir düzeltim olduğu düşünülebilir. Bu bakımdan aletheia insan sonluluğunun maddesel olmasa da tinsel boyutta olumsuzlaması anlamına gelmektedir. Bu olumsuzlama çabası insanın sonluluk bilincine sahip bir varlık olmasında temellenmektedir. Antik Çağ inanma kültürlerinde ölüm sonrası boyut, insanın yaşamda yaptıkları doğrultusunda ödül ve ya cezayla karşılaştığı boyuttur. Lethe uygulamasını ceza olarak düşünürsek, anamnesis cezadan kurtuluş çabası, aletheia ise cezanın bu boyutunun yani yok edilmiş hakikat algısı ve bilincinin geri gelmesi olarak cezanın bitmesi anlamına gelir. Platon için de ruh ölümsüzdür. Phaidon Diyaloğu'nda Platon, Sokrates ile Cebes ve Simmias adlı iki Atinalı arasında geçen diyalogda ruhun ölümsüzlügünü kanıtlamaya calışır. İlk argüman olan döngüsel argümanda Sokrates, Cebes'e canlı olmanın bir zıttı olup olmadığını sorarak var olan şeylerin zıtlıklardan gelip zıtlıklara gittiği argümanı üzerinde yoğunlaşır. Böylece ölümün yaşamdan, yaşamın ölümden doğduğu belirtilir (Phaidon: 3435). Platon bu sonucun yalnızca yeniden doğuşa değil aynı zamanda ruhun sonsuz göçüne de kanıt teşkil ettiğini düşünür. Platon'a göre insan unuttuğunu yaşamaya mahkum edilmiştir. $\mathrm{Bu}$ mahkumiyet insanın kendini bilmesine yani kendi gerçekliğine olan yabancılaşmasını anamnesis aracilığıyla aşmasına dek sürmektedir.

Platon, Heidegger'den çok önce örtük de olsa insanın ontik varlığının ve bilme yetisi olan aklının sonlu yapısını keşfederek (ki bu sonluluk Heidegger için ontolojik bilgiye karşıllk gelmektedir) bilgiyi kuran saf aklın yönelimsel (intentional) etkinliğinde temellenen aşkınsal yapısı yerine birbirine indirgenemeyen her iki varlık alanı arasında aracilık yapan ve bir nevi anlama yetisi işlevi gören anamnesis kavramını kullanır. Ayrıca Platon tarafından ayrılmış söz konusu varlık alanları, biri diğeri adına ya da karşısında değersiz görülebilse de biri diğeri adına ya da karşısında tamamen yadsınamaz. Aristoteles Planton'u, görünüşler dünyasını yani oluşa ve bozuluşa tabi olan dünyayı oluşa ve bozuluşa tabi olmayan idealar dünyasıyla açıkladığı için eleştirirken aynı zamanda Platon'u idealar kuramına yönelten temel düşüncenin, en açık ifadesini Parenides'te bulduğumuz, "duyuların yanıltıcılığg" düşüncesi olduğunu belirtir (Aristoteles, 1996:124-143). Platon, Parmenides'in oluşu paranteze alan yanlışına düşmeden oluş dünyasının ontik varlığını kabul etmiş fakat 
oluşun ilkelerini oluş dünyasında temellendirmemiştir. Platon'un düalist evren tasarımı bu bağlamda birbirinden keskin şekilde ayrılması gereken, birbirinden bağımsız var olabilecek farklı gerçeklik alanlarını ve dünyaları ifade etmekten ziyade gerçekliğin iki farklı yönünü ifade eder.

Diğer yandan insan, sonluluğunun bunalımını yok etmek adına fenomen evrende tinsel olanı konumlandırmaya calışmaktadır. Ancak maddesel olan üzerine tinsel bilinç geliştirmek maddesel olanla tinsel olanın tanımına aykırıdır. Maddesel olandan hareketle tasarlanmış ve ya sıfır noktası maddesel olan kabul edilmiş; başka deyişle devindirici gücü ve ya teşviki maddesel olandan devşirilmiş olan her tinsellik tasarımı tamamen tinsel olmayacaktır. Zira Platon için tinsel olan tanımı gereği içinde duyumlanabilir olanı barındırmamalıdır. Tamamiyle maddesel olan açısından tinsellik bir pasifizm; tamamen tinsel olan açısından maddesellik bir aldatmacadır. Özü gereği bu iki alan bir ve aynı olamayacağı için insanın maddesel yanıyla tinsel yanı gerilim içerisindedir. Bu bağlamda Platon'da örtük halde bulunan aletheianın bu yönü daha sonra Heidegger'de en açık ifadesine ve anlamına ulaşacağı gibi insanın bu gerilimden kaynaklanan kaygısına ve olanaksızlığına bir çözüm arayışıdır.

\section{II}

Düalist yapının fenomenler tarafındaki varlıkların ve bu varlıklar yoluyla yapılan pratiklerin değerlerini ideasal hakikate borçlu olmaları bize sanatsal eylemin epistemolojik eleştirisine dair ipuçlari verir. Görünüşler dünyasındaki nesneler yani bu dünyada etrafımızı kuşatan nesneler idealardan pay alarak görünüşler dünyasında varlıklarını bulmuş idea taklitleridir. Sanat yapitları ise hâlihazırda ideaların taklidi olan nesnelerin birer benzetimi olarak taklit olanin taklididir. Bu anlamda sanat yapitları her ne kadar nesnelerden, eylemlerden ve de kavramlardan ilham alarak ideal olana öykünme gayretinde olsalar da, bu yapıtlardan çıarılabilecek bilgi Platon için episteme karşısında değersizdir.

Platon gerçeklik ve yanılsama ayrımı yaparken zihninde gri alanlara sahip olmayı istemeyen bir görünüm vermektedir. Bir şey ya kendisi olmalıdır ya da büsbütün başka bir şey olmalıdır. Aynı şekilde bilgelik ile de şüpheden uzak bir ilişki kurulmalıdır. Ancak Platon için sanatçı hakikatin kendisiyle değil onun yansımalarıyla ilgilenir. Bu nedenle sanatçı, filozof olmaktan uzaktır. "Bilgeliği bütünüyle seven kişiye filozof denebilir, yoksa onun bir parçasıyla ilgilenip diğer parçalarını görmezden 
gelene değil" (Platon, 2009:475b). Taklitçilik hakikati bulmaya çalışmak noktasında aylaklık edip sanılara bağlanmaktır.

Sanatçılar, öykünme yolunu kullanan öykünücülerdir. Sanat yapıtları tanrısal kanundan türetilen gerçek fenomenler değil, görünüşlerden türetilen kopya görünüşlerdir. Görünüşler dünyasındaki şeyler hâlihazırda ideaların mimesis' $i^{4}$ olduğu için sanatçıların yaptığı şey mimesis mimeteos (taklidin taklidi), sanatçı ise mimetes (taklitçi)'dir. Görünüşler epistemeden aşağ 1 bilgisel değerdedirler. Bu sebeplesanatsal faaliyet bilmeedimini amaç edinse dahi bilinen üzerine bilmeyenlerin yaptığı bir faaliyettir, ve sanatçı bu faaliyetinde bilen olduğunu düşündüğü müddetçe bilinmeyeni tekrar ettiğini fark edemez. Görünüşler üzerinden yapılacak ilerici faaliyet ancak görünüşlerin ardındaki tanrısal kanunu, ruhu anamnesise zorlayacak araştırmalar yoluyla anlamaya çalışmak olabilir; fakat aksine görünüşler üzerinden yine görünüşlerin görüntülerini, görünüş versiyonlarının ya da kopyalamalarını elde edecek bir sanatsal uğraş Platon için gericidir.

Böyle taklitleri yapmayı kölelere ve ücretli yabancılara buyurmalıyız. Bunlarla ilgili olarak ciddi bir işe hiç kimse hiç bir zaman girişmesin. Ne kadın ne erkek hiçbir özgür yurttaş bunları öğrenip ortaya çımasın ve bu taklitlere her zaman bir yenilik bulunsun. Hepimizin komedya dedigi bu gülünç eğlenceler yasada ve kuramda böyle dursun, bizdeki tragedya ozanları gibi ciddi taklit yapanlardan bazıları birgün çıkıp gelseler ve "Yabancılar, devletinize ve ülkenize girelim mi? Eserlerimizi de getirelim mi?" diye sorsalar bana kalırsa yanıtımız şöyle olurdu: “Değerli yabancılar, biz kendimiz elimizden geldiğince en güzel ve en üstün tragedya yazan ozanlarız, nitekim bizim tüm devlet düzenimiz en en güzel ve en üstün yaşamın taklididir, bunun da aslında en dogru tragedya oldugunu ileri sürüyoruz" (Platon, 2007:816d-817b).

Sanatçının mimetik yolla meydana getirdiği sanat yapıtının idealar karşısında ve ya ideaları kavrama yolunda değeri bulunmamaktadır. İdea bilgisine ulaşmak için görünüş dünyasının doğru okunması gerekmektedir, fakat mimetik faaliyet görünüş dünyasında görünüşlerin ikincil kopyalamalarını yaparak bu okumayı zorlaştırmaktadır. "Eğer bu doğruysa, eğer bütün mimetik sanatlar 'görüntü-model' pratiğiyse, bunun

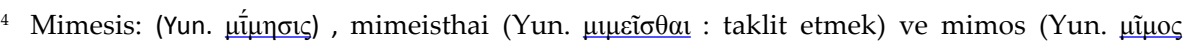
: taklitcilik) kelimeleriyle kökensel bağlantıya sahip olup taklit, kopya, sunu, mimik, tarif, benzetim anlamlarına gelmektedir (Peters, 2004:221-224) \& (Poetika:1447a). 
anlamı sanatın dünyanın tanımlanması anlamına gelemeyeceği ve dünya hakkında ortalama bir hakikat (ve ya sahtelik) teşkil edemeyeceğidir, belki ancak mimetik sanat uyumlu olduğu şeyleri temsil edebilir" (Halliwell, 2002:46).

Sanatçı nesnenin ontik farkındalığını üretemez. Sanatçının ürettiği ürünler hakkında ontolojik olarak söylenebilecek tek şey ürünlerinin kopya varlıklar olduğudur. Bu kopya varlıkların varlıklarını yadsıyamıyoruz, yine de onlardan, ontolojik hakikati öğrendiğimizi söyleyemiyoruz. Sanatsal faaliyet ideanın kendisini değil o ideadan pay almış nesnenin ya da kavramın benzerini yapmaktan ibarettir. Öyleyse bu faaliyetler halihazırda var olmayan bir şeyi varlığa geçiremiyorlarsa ve ya varoluş sürecindeki bir şeye dahil olamıyorlarsa sanat ve zanaatçların faaliyetlerinde bir varoluş ya da var ediş yoktur (Platon, 2009: X:597). Sanatçı, ideaları doğrudan kopya etme konusunda yetkinsizdir.

Mimetik yaratımlar görünüşlerin yansımaları veyahut görünüşlerin üzerine düşen gölgeler gibidirler. Bu yaratımlar görünüşten yani fenomenden yeni fenomenler türetmektir. Buna epiphenomenon da denebilir (epi: Yun. غ̇ंí, Ing. on, upon, at: üzerine, üstüne/ fenomen: görünüş ya da deneyimde farkındalığın anlık objesi). Görünüş üzerinden görünüş yaratmak, epistemolojik açıdan hakikatin ikincil kere kırılması (bölünmesi, türemesi) anlamına gelir ve her bir yaratmada hakikat bir kez daha kırılacaktır. Mimetik faaliyet nesnenin özünü yaratamaz. Mimetes bir bilinçsizlik içerisindedir. Platon, sanatçının bilinçsizliğinden kaynaklanan temsiliyet ve temsilcilik fikrini eleştirir. Bir heykeltıraş bir kundura heykeli yaparsa yaptığı şey kunduranın kendisi değil, kunduranın işlevselliğinden uzak benzetimi olacaktır. Platon için mimetesin bu tavrı onun kundura hakkında (form, işlev, kullanım) bilgi sahibi olduğuna dair hükme varmasıdır.

Her araç gerecin, her canlı varlığın ve her eylemin kusursuzluğu, güzelliği ve doğruluğu, sadece, bunların yapılması, yaratılması ve büyümesi sirasında göz önünde tutulan kullanıma hizmet etmez mi?... Peki taklitçinin durumu nedir? Resmini yaptığ 1 nesne hakkında, onun güzelliği ve doğruluğu hakkında, onu kullanmaktan ileri gelen deneyime dayalı bir uzmanlıkwoksa sırf işten anlayan bir uzmanla yan yana gelmeye mecbur kalmış olduğu ve kendisine nasıl resim yapılması gerektiğini gösterdikleri için bu konuda doğru bir düşünceye mi sahiptir? Öyleyse taklitçi taklidi 
yapılan nesneler hakkında ne bir uzmanlık bilgisine sahiptir, ne de güzelliği ve çirkinliği konusunda doğru dürüst bir fikre (Platon, 2009: X: 601d-602a).

Taklitçinin yapıtı tamamen "bakış açısına" bulanmıştır ve bakış açısının her değişim ve deviniminde yapıt yeniden değişir. Devingen bakış açısı yalnız sanatçıya özgü değil aynı zamanda alımlayıcıya da ait bir özellik haline gelmektedir. Her değişimde taklit olan yeni bir taklide dönüşmektedir. Fakat taklidin kendi üzerine bu bükülmesi ne kadar değişirse değişsin ideanın kendisini vermez. "Demek ki taklit sanatı hakikatten alabildiğine uzaktır, tam da bu nedenle her şeyin çok az yanını kavradığı ve bu da o şeyin sadece görünüşü olduğu için önüne çıkan her şeyi taklit eder" (Platon, 2009: X:598c). Mimetik yaratımlar ya da semboller kendilerinden başka şeyi temsil etme becerisine sahip olabilirler, fakat bu onları temsil ettikleri şeyin kendisi yapmaz. Böylelikle taklit hakikat adına bakıldığında üçüncü derece bir ilintidir (Platon, 2009: X: 601d-602c).

Platon mimetik sanat eylemi elştirisini reel dünya sanatının epistemolojik hakikatle ilişkisindeki mantıksızlıkları üzerinden yürütür. Buna göre:

I) Platon sanatçılardan sadece yaratıcı eylemin basit prensiplerinin bilincinde olmalarını istemez; aynı zamanda sanatçılardan sanatsal taklitlerden ya da kopyalamalardan türetilerek bilinebilecek her şeyi bilmelerini bekler. Bu durum sanatsal yaratım için gerekli olsa da yeterli değildir. Bu bir yeterlilik değildir çünkü bir masa ya da kanepe üretmek icin gerekli olan bilinç bir objeyi boyamakta gereken bilinç ile özdeş değildir.

II) Eğer sanatçlar şeyleri yaratmak icin gerekli olan her şeyi bilselerdi sonunda Tanrı gibi olurlardı. Çünkü Platon'un argümanına göre reel varlıga sahip her şeyi yaratabilecek tek kişi Tanrı'dır.

III) Platon'un görüşünde "hakikat", sanatçının özgün bilinciyle ve kapasitesiyle sağlayamayacagı türden objelerin üst ifadesidir. Bu sanatsal eylem aldatıcıdır (Neumaier, 2010:311).

Herhangi bir faaliyetin Platon açısından değerlendirilmesi temelde basit bir soruya dayanmaktadır: bu faaliyet idea hakikatine, gerçekliğe dahası insanın kendini bilmesine hizmet ediyor mu? Mimetik yaratımın yani sanat 
yapıtının fonksiyonu Platon için bir tür göreneği devam ettirmektir. Bu göreneklerden olan sanat gerçekte taklit edilenin ideasının bilinmemesi bir yana estetik beğeninin temel kavramı olan güzel kavramının renk, simetri, ses, form gibi kıstaslardan arınmış kendiliği bilinmeden yapılır. Yine de Platon'un söylemek istediği sanat alanının tamamen bilgiden yoksun olduğu değil, sanat bilgisinin ruhta aşağı bir bilgi değerine sahip olduğu ve sanat pratiğinin ideaları kavramak noktasında yanıltıcı olduğudur. Sanat yapıtının içeriği güzel ideasi hakkında ipuçları içerebilir. Bu içerikten yani renk, ses, simetri, form gibi sanat eserini oluşturan niteliklerin yorum tarzından bir güzellik kavrayışı edinilebilir.

Öte yandan odaklanılması gereken bir başka nokta, hiyerarşik bilgi düzeninde hangi bilgi alanının ne kadar değerli olduğu değil bu bilgi alanlarının neden "bu" kadar değerli olduğudur. Bilgi alanları, insanın kendini bilmesine hizmet ederek epistemolojik ve ontolojik farkındalık yaratarak onu erdemli bir yaşama yaklaştırdıkları ya da yaklaştırmadıkları için değerlidirler ya da az değerlidirler. Şöyle ki, eğer gerçeklik ve gerçek olmamaklık (yanılsama, imitasyon, ilizyon, doxa) kutupları arasında bilgi değersel olarak bir hiyerarşilendirmeden bahsediyorsak, -insan içinher bir bilgi alanında niceliksel oranlardan da bahsetmiş oluruz. Yani bilgi değersel olarak en üstte bulunan episteme alanında gerçeklik en fazla, gerçek olmamaklık en az; bilgi değersel olarak en aşağıda bulunan eikasia alanında gerçeklik en az, gerçek olmamaklık en fazladır. Bu bilgi alanlarının yani eikasia, pistis, dianomia, epistme alanlarının görünüşler dünyasındaki öğretileri olan sanat, zanaat, matematik, diyalektik öğretilerinin, gerçekliğe uzaklığı belirten birer konum olduğunu görürüz. $\mathrm{Bu}$ konum aynı zamanda farkındalık diye kavramlaştırabileceğimiz, Sokrates'in bilginliğin olabilecek tek kriteri olarak gördüğü bilmediğinin bilgisine sahip olmaya olan konumdur.

Tanrısal istencin hakim olduğu evrende insanın farkındalığ idealara yükselme süreci boyunca devam eder. Görünüşler dünyasının yanılsamalarını insan ancak akıl kapasitesini doğru kullanırsa aşabilir. İyi ideasi ruh için bir erektir ve görünüşler dünyasının tüm içeriği hakikate ulaşmak adına aşılması gereken basamaklardır. Sanat bu aşma amacıyla çatışmaktadır. Çünkü sanat insanın kendini ifade ediş biçimlerinden biridir fakat bu biçim hakikatin gölgesinde yapılan ikincil bir gölge oyununa benzemektedir. Platon için görünüşlerin dünyasında, görünüşlerin dünyasını aşamayan ve de bu aşmamaya katkıda bulunan sanat etkinliği bilginin kaynağı olmaktan çok uzaktadır. Çünkü sanat dünyayı açılamak 
yerine onu gizlemektedir.

Platon'da gizlenmişlik, evrene hakim idea yasasının veidea realitesinin unutulmuş olması dolayımıyla bilinmemezliğidir; bu bilinmemezlik, unutulmuşluğun (lethe) geri çevrime zorlanmasıyla giderilir. Böylelikle bilinmemezliğin giderilmesi şeklinde gerçekleşen bilme edimi ve bilgi edinimi (episteme), Platon felsefesinde hakikatin kendini gerçekleştirme şeklidir.

\section{III}

Heidegger'de hakikatin hakikat oluşu, onun kendisini varlık alanında açığa vurmasıyla bağlantılıdır. Heidegger için hakikatin gerçekleşmesi her bir açıklığa gelişte gerçekleşmesidir, yoksa Platon'da olduğu gibi hakikatin hakikat oluşu yalnızca aşkın idea yasası hakemliğine bağlanmış değildir. Heidegger'de hakikatin gizlenmişliği ya da gizlenmişlik, varlığın varoluşuna dair bir henüz bilinmemişliği ifade eder. Hakikat, bu bilinmemezliğin her bir açılımında aşkın bir ölçüt gerektirmeksizin gerçekleştirmektedir. "Hakikat kendini eserde görünür kılar. Aydınlık ve gizlenmişlik arasındaki münakaşa olarak hakikatin varlığ 1 dünya ve yeryüzünün devinimsizliğindedir" (Heidegger, 1977:50). Bu bağlamda sanat yapitındaki herhangi bir meydana geliş, hakikatin kendisini gerçekleştirmesinin bir türüdür. Ve bu eserde meydana gelen, kendini gerçekleştiren hakikatin hakikat oluşunun ölçütü yine kendisindedir. Başka bir deyişle sanat eserindeki hakikat, hakikat oluşunu kendinde barındırır. "Eserdeki hakikat gerçekleşmesi eserdedir" (Heidegger, 1977:45).

Gizini kaldırmak anlamında kullanılan aletheia kendini, görünür kılma ve ya görünür kılınma biçimleri içerisinde gösterir. Gizin kalkması biçimindeki bir varoluş sırasında varoluş içinde bulunan şey, insan bilinci için üzerine konuşulabilir hale geldiğinde artık bir gerçekliği ya da hakikati ifade eder. Çünkü görünür ve konuşulur olan, yani fenomen olan aynı zamanda hakiki olandır.

Fenomen kavramının dayandığı Yunanca'daki phainomenon ifadesi 'kendini gösterme' anlamına gelen phainesthai fiilinden türetilmiştir. Dolayısıyla phainomenon şu demektir: kendini gösteren, tezahür eden, ayan olan. Öte yandan phainesthai sözcüğü, phaion'un (gün züyüne çıkarma, ışığa getirme) orta-sesli hali olup , pha- köküne 
aittir (pha sözcügündeki gibi: 1şık, aydınlık; yani içinde bir şeyin kendini belli edebilecegi, kendinde görünür kilabileceği şey). O halde fenomen ifadesinin anlamı bakımından şunu tespit edebiliriz: kendini-kendinde gösteren, ayan olan. Dolayısıyla phainomena (fenomenler), gün ışı̆̆ında bulunan ya da ışığa çıkarılabilenlerin tümlüğü anlamına gelmektedir ki, Yunanlılar bunu genellikle basitçe ta onta (var olan) ile özdeşleştirmişlerdir (Heidegger, 2008:29).

Varlığı gizlilikten kurtaran (keşfeden) da hakikatin bir parçası olmaktadır. "Keşfedici varlık olarak hakiki oluş, Dasein'ın bir varlık minvalidir. Dolayısıyla bu keşfetmeyi bizatihi mümkün kılana, çok daha asli bir anlamda 'hakiki' denmesi gerekir mecburen" (Heidegger, 2008:232). Varlığın gizlilikten kurtarılması ve açımlanması, açımlayıcı varlık tarafından mümkün kılınmaktadır. Açımlayıcı varlık (var-olan şey ya da özne) gizli bulunanı keşfettiği müddetçe kendi hakikatini var kılmaktadır.

Hakikate çıkmış olanın hakikiliği, kendisi ve keşfedicisi çerçevesine hapsolmuştur. "Keşfedilen ve açımlananlar; lakırdı, merak ve müphemiyet yüzünden tebdil ve kapalılık halindedir" (Heidegger, 2008:234). Heidegger için Dasein, açımlanmış olanın açımlanmışlığını değişkenlik, belirsizlik ve unutuş ihtimallerine karşı korumalı ve yenilemelidir.

Bu sebepten dolayı Dasein, daha önce keşfedilmiş olanları da zevahir ve ya tebdil ihtimaline karşı açıklıkla kendine maletmeli ve onların keşfedilmişliğini hep teminat altına almalıdır. Yine aynı şekilde, her türlü yeni keşif de hiçbir zaman tam bir mahfuzluk zemini üzerinde icra edilmeyerek keşfedilmişliğin zevahir halinden hareketle gerçekleşmektedir. Varolanların şöyle ya da böyle görünüyor olması demek, onların belirli bir surette zaten keşfedilmiş olmaları ve ya halihazırda tebdil içinde olmaları demektir. Hakikati (keşfedilmişliği) varolanlardan hep çekip çıarmak gerekir (Heidegger, 2008:234).

Tasarımın Dasein'ın var oluş yapısına ait olması sayesinde (Heidegger, 2008:234) açımlayıcı varlık, açımlanmış olanları yani hakikati, bahsi gecen değişkenlik, belirsizlik ve unutkanlık durumlarına karşılık yeniden tasarımlayabilmektedir. Buradan hareketle sanat eylemi ve sanat yapıtı, yapıcının bir hakikati ve ya keşfettiği/keşfedilmiş kendi hakikatini kendisine açımlaması anlamına gelebilmektedir. Zira sanat yapıtı, hakikat üzerine farklı bakış açılarının ve ya hakikatin kendiliğinin korunması 
şartıyla farklı versiyonlarının yaratılmasına müsaade etmektedir.

Heidegger için, aletheia kavramını 'gizlenmiş bulunanın açığa çıkarıltılması' anlamında kullanmak sanat yapıtının, sanatçının ve sanatın neliğinin ve neredenliğinin, yani kökeninin sorgulanmasıdır. Çünkü şeyin kökeninin ne olduğu sorusu, o şeyin hakikatinin ne olduğu sorusudur.

\begin{abstract}
'Köken' burada, bir şeyin nereden ve ne vasitasıyla; ne olduğu ve nasıl olduğu anlamındadır. Bir şeyin ne olduğuna ve nasıl olduğuna var oluş diyoruz. Bir şeyin kökeni onun varlığının özüdür. Sanat yapıtının kökeni hakkındaki soru, onun özünün kökenini sorar. Sıradan bakış açısına göre yapıt, sanatçının aktivitesinden ve aktivitesi aracılığıyla ortaya çıkar. Fakat sanatçı nereden ve ne şekilde var olur, sanatçı nedir? Yapıt aracılığıyla var olur, çünkü yapıt ustasını över, bu demektir ki: yapıtın varlığı sanatçıyı, sanat ustası olarak varlığa çıkarır. Sanatçı yapıtın kökenidir, yapıt sanatçının kökenidir. Diğeri olmadan biri var olamaz. Biri yalnız başına diğerinin vasfını taşıyamaz. Sanatçı ve yapıt, sanatçı ve sanat yapıtına adını kazandıran temel bir üçüncü, yani sanat sayesinde birbiri arasında referans verirler (Heidegger, 1977:7).
\end{abstract}

Heidegger için yapıt öncesi bir -belirli- alan, yeryüzünün bir şey ifade etmeyen, daha doğrusu bir şey ifade etme hususunda pasif ve sakin durumda olan alandır. Yapıt, yapıtlaştığı yeri tanımlayan ve bir nevi dünyaya açan bir fenomene dönüşmektedir. Çünkü yapıt, yapıtlaştığı bu yer ile belirli bir ilişkiler ağı içerisinde var olmuştur. "Bir yapıt nereye aittir? O ancak kendi aracılığıyla açılan alana aittir" (Heidegger, 1977:31). Yapıt, bir varlığa getirme ve bir üretme biçimidir. Bu sebeple üzerine konuşulabilen diğer tüm ontik gerçeklikler gibi sanat yapıtları da ontik gerçekliklerdir.

\title{
Sonuç
}

Aletheia kavramı, hakikatin olumsuzlanmasının görünüşler dünyasında tekrar olumsuzlanması yoluyla tersine işletilmesinin en salt halidir. Bu tersine süreç, ruh-beden ikiliğiyle bir şekilde bu dünyaya gelmiş insanın ontolojik ve epistemolojik olarak kendini buluşunun ifadesidir. Bu sürecin sonunun insanın bedensel yanıyla bakıldığında (buluş kelimesinin olumlu içerimi göz önüne alınırsa) ironik şekilde hiçliğe; ruhsal olarak 
bakıldığında ise bir arınmaya çıktığını görürüz. Zira beden, hakikatin bedene hitap eden her türlü aldatıcı sanı, algı, haz, duygudan bağımsız olduğu, bedensel olanın anlamsızlaştığı bir boyuta çıkar. Diğer yandan ruh, bedenle birleşmesi ve görünüşler dünyasına gelmesiyle içine düştüğü hafıza kaybından kurtulur, görünüşler dünyasında aralarında yaşamak zorunda kaldığı tüm gölgeleri geride bırakır. Ölüm ancak bedenin formunu bozabilir, ruh için ölümün bir anlamı yoktur. Bedenin ölümlü doğasının kabullenilmesi insanı bedensel olanı aşan erdemli bir yaşama götürecek ilk farkındalıktır. "Güç olan ölümden kaçınmak değil Atinalılar, kötülükten kaçınmaktır. Çünkü kötülük ölümden daha hızlı koşar" (Platon, 2010 XXIX: 39a).

İnsanlığın özgürlüğü değil belki de ama erdemli yaşayışı aletheia'ya bağlıdır. Her ne kadar Platon felsefesinde dünyevi olan ve tinsel olan arasında tinsel olanı üste daha üste koyma refleksi gösteriyor olsak da, aletheia'ya ulaşma meselesinde bedensel olanın hakkını teslim etmemiz gerekmektedir. Anamnesis, ruhun önceden bildiği şeyi hatırlamasıdır yine de bu hatırlamayı bedensel tecrübe tetiklemektedir. Menon'un kölesinin Sokrates tarafından sorguya çekilmesi bedensel bir tecrübeyi de barındırır, fakat sorgulanan gerçekte ruhtur. Anamnesis süreci şöyle işler: bilgelik peşinde koşma olarak philosophia bedensel tecrübe yoluyla ruhu hatırlamaya zorlar, ruh sorgunun niteliğiyle doğru orantılı olarak anamnesis faaliyetinde bulunur ve aletheia'ya ulaşır. Yani kavrayış tinsel bir boyutta olmasına karşın dünyevi olanla birlikte hareket eder. Bu birlikte işleyiş evrenin Platonik düalizminde en altta yer alan eikasiayı rahatsız etmek ve bozuma uğratmaya çalışmakla başlamaktadır. Dünyevi olan bozuma uğratıldığı oranda evren düalizminin üst seviyelerinde olan dianomia ve episteme, çıkarım ve diyalektik yoluyla; başka deyiş̧le muhakeme ve akıl yürütme yoluyla kavranılır. Nihayetinde erdemli yaşamaya bağlı olarak ruh yetkinleşir.

Diğer yandan Platon'un aletheia tasarımı insana, insanın epistemeye ulaşmaya çalışmadığı sürece üstten bakıldığı muhafazakar bir tasarımdır. Çünkü görünüşler dünyasına iyi ideasının tanrısal gerçekliği hakimdir, ancak bu hakimiyet kendini görünüşler dünyasında pistis yani inanç ve eikasia yani sanı olarak adlandırdığımız imgelerde gizlemiştir. İmgeler gölgelerdir. Bu gerçeklik kendini dayatmaktadır. Zira gölge onu yaratan cisme muhtaçtır. Bu muhtaçlık ilişkisinin karanlık tarafında yaşayan insan, Platon için gölgenin neyin gölgesi olduğunu anlamaya ve gölgeyi yaratan ışığın kendisini bulmaya zorlanmalıdır. Yine de bu dayatma, ne 
sonunda ideanın kendini tüm açıklığıyla göstereceğine dair bir vaad, ne de varılması kaçınılmaz totaliter bir kaderdir. Gerçeklik öylece durur, insanın bu gerçekliği inkar edecek ya da onu değiştirecek gücü yoktur. Platon görünüşler dünyasının yozlaştırıcı içerimlerini tinsel dünyanın yapıcılığıyla gidermeye çalışır. $\mathrm{O}$, bu giderimi insan türünün kendini düzeltmesi ve işlemesi olarak okumaktadır. Görünüşler dünyasını yozlaştıran başlıca faaliyetler olarak içerisinde hareket, değişim, rölativizm ve taklitçiliğin dolu olduğu siyasa, söylev, zanaat, sanat faaliyetlerini görür ${ }^{5}$. Felsefi yaşamı boyunca bu faaliyetleri eleştirmiş ve bunların hakikate yakın alternatiflerini yaratmaya çalışmıştır. Bu çaba bir yandan ideal olanı anlatma çabasıyken diğer yandan Sokrates' in ölümüne sebep olan philosophia etkinliğini toplumda anlaşılır kılmak ve de philosophianın devletin ve toplumun her kademesinin düzenlenmesine nasıl yardım edebileceğini anlatma çabasıydı.

Platon'un sanat ve sanatçıyı doxa pratikçileri olarak görmesi sanata ve sanatçıya düşmanlık ya da aşağılama nasihati olarak düşünülmemelidir. Onun demek istediği sanat yapıtı yoluyla insanın "kendini bilemeyeceğidir". Mimetik faaliyet, otonomluğunu kaybetmiş yeryüzü insanının doxa yaşantısını pekiştirmektedir. Bu bir kısır döngüdür, zira görünüşler dünyasının mimetik içeriği insan için bir yabancılaşma pratiğidir. Çünkü mimetik faaliyet insanı doğaya, kendisine ve en önemlisi hakikate yabancılaştırır. Sanat, doğayı ve toplumu taklit etmenin yanında onu aşma becerisine sahip değildir. Sanat içerisinde ontolojik ve ya epistemolojik bir çıkarsama yoktur. Bu sebeple sanat öğrenmenin bir parçası sayılamaz, o sadece göreneğin başka göreneklere kapı açmasıdır. Sanatın neyi taklit ettiğinin, taklit ettiği şeyi nasıl taklit ettiğinin ve bu taklidi ne yoluyla taklit ettiğinin bir önemi yoktur. Önemli olan onun hakikat karşısındaki olumsuz içerimidir.

Heidegger için sanatsal eylemler Platon'da olduğu gibi gerçekliği gizleyen, hakikatin yozlaşmasına sebebiyet veren, fenomenlerin kötü kopyalamaları, epistemolojik olarak değerleri bulunmayan ve ya ontik olana kapı aralamayan eylemler değillerdir. Bundan ziyade sanatsal eylem

\footnotetext{
7 Platon, hocası Sokrates'i ölüme mahkûm eden Atina toplumunu ve bu toplumun siyasal, sanatsal ve zanaatsal içeriğini eserleri boyunca hep eleştirir. Ki Sokrates'in Savunması'nda söylendiği üzere Sokrates'e dava açanlardan Meletos ozanların, Anytos el isçilerinin, Lykon da söylevcilerin philosophia düşmanlığının temsilcileridir (S. Savunması, X: 23e). Sokrates'in ölümünün yarattı̆̆ travma Platon'un toplumun her yönüyle örgütlenmesini felsefenin en önemli sorunları arasında görmesine neden olmuştur. "Sokrates'in ölümü bir skandal ve sitenin islediği bir cinayettir" (Brun, 2007:30).
} 
hakikatin kendini açmasının yollarından biridir. Heidegger'in sanatsal eylemi, hakikatin kendini gerçekleştirme halinde olmasının bir türü olarak görmesi Platon'un aletheia bağlamında sanat eylemi değerlendirmesiyle çatışıktır. Bunun temel sebeplerinden biri Heidegger'in aletheia kavramının anlamsal içeriğine sadık kalarak ontik olanı değerlendirmesi ve de açıga çıkarma kavramını Platon'da olduğu gibi yalnız ideanın varlığının değil tüm varolanların varlığının açığa çıkarılması bağlamında okumasıdır. Onun için var olan her şey, insan bilinci değmis olsun ya da olmasın aşkın ölçüt karşısında yargılanmaksızın vardırlar. Her ontik olan kendi ontik hakikatinde vardır. "Hakikat, varolan/varoluş olarak varolanın/var-oluşun açıklığı/gizlenmemişliğidir" (Heidegger, 1977:68).

Sanat yapıtı, yeryüzünde kendiliğinden duran - bu insan için henüz bilinmemiş olan ve henüz açılmamış demektir- olarak var olanı açmaktadır. Böylece hakikati, var olanı gizlilikten ayırma ve -artıkaçığa çıkarma olarak kabul ettiğimiz sürece Heidegger için yapıtta bir hakikat gerçekleşmektedir. "Hakikat nedir? Hakikat gerçeğin varlığıdır. Varlık (var olmaklık) dediğimizde ne düşünürüz?...Hakikat, hakikatin varlığıdır. Bunu düşünmekle Yunanca gizlenmemişlik ${ }^{6}$ anlamına gelen $\alpha \lambda \eta \eta \theta \varepsilon ı \alpha$ (aletheia) kelimesini hatırlarız" (Heidegger, 1977:40). Heidegger için aletheia kavramında mantıksal bir karşılıklı muhtaçlık ilişkisi yatmaktadır. $\mathrm{O}$, hakikatin açığa çıkmakla gizli bulunmak arasındaki salınımda açığa çıktığını söyler. Aletheia, açığa çıkma eylemine ihtiyaç duyar, başka deyişle aletheia gizlenmiş olanın gizliliğinin bozumuna ihtiyaç duyar. Açığa çıkmışlık ancak açığa çıkmamışlıkla vardır. "Fakat hakikat nasıl meydana gelir? Şöyle cevaplarız: o basit esaslarda meydana gelir. Hakikatin oluş esaslarından biri, yapıtın yapıt-oluş varlığıdır. Bir dünya kurmak ve yeryüzü üretmek, gizlenmişliğin bütündeki varlığının yani hakikatin savaşım içindeki çatışkısal yapıtıdır" (Heidegger, 1977:44).

Derviş Atahan, Mersin Üniversitesi, Türkiye Zehragül Aşkın, Mersin Üniversitesi, Türkiye

8 Gizli olmanın tersi durumu ya da açığa çıkmışlık. (Alm.: Unverborgenheit, İng.: unhiddenness) 


\section{Kaynakça}

Aristoteles. (1996). Metafizik, (Çev. A. Arslan), İstanbul: Sosyal Yayınları Brun, J. (2007). Platon Ve Akademia, (Çev. I. Yerguz), Ankara: Dost Yayınları

Halliwell, S. (2002). The Aesthetics Of Mimesis- Ancient Texts and Modern Problems, New Jersey: Princeton University Press

Hard, R. (2004). The Routledge Handbook Of Greek Mythology, New York: Routledge Taylor \& Francis Group

Heidegger, M. (1977). Der Ursprung des Kunstwerkes, Frankfurt am Main: Vittorio Klostermann

Heidegger, M. (2008). Varlık Ve Zaman, (Çev. K.H. Ökten),Istanbul: Agora Kitaplığı Moles, J. N. (2015). Aletheia: Remembering And Enlivening, Journal Of Applied Hermeneutics, April -22

Monchamp, M. (2008). Aletheia- Truth Of The Past, Journal Humanity

Neumaier, O. (2010). Are Works of Art Simply Imitations Of Shadows? (Ed. Diana Teters): Metamophoses Of The Worlds: Traces, Shadows, Reflections, Echoes and Metaphors, pp: 308-326

Peters, F. (2004). Antik Yunan Felsefesi Terimleri Sözlüğ̈̈, (Çev. Hakkı Hünler), İstanbul: Paradigma Yayınları

Platon, (1975). Diyaloglar, (Çev. Hürriyet Kolektif), Istanbul: Hürriyet Yayınları

Platon, (2000). Symposion- Şölen, (Çev. Cenap Karakaya), İstanbul: Sosyal Yayınları

Platon, (2007). Yasalar, (Çev. S. Babür, C. Şentuna), İstanbul: Kabalcı Yayınları

Platon, (2009). Devlet, (Çev. S. Eyüboğlu- M. Cimgöz), İstanbul: İş Bankası Kültür Yayınları

Platon, (2010). Diyaloglar, (Çev. Kolektif), İstanbul: Remzi Kitabevi 